\title{
Scleroderma minutisporum, a new earthball from the Amazon rainforest
}

\author{
Alfredo DS ${ }^{1}$, Leite $\mathrm{AG}^{1}$, Braga-Neto $\mathrm{R}^{2}$, Cortez $\mathrm{VG}^{3}$ and Baseia $\mathrm{IG}^{4 *}$ \\ ${ }^{1}$ Universidade Federal do Rio Grande do Norte, Programa de Pós-Graduação em Sistemática e Evolução, Centro de \\ Biociências, Campus Universitário, 59072-970, Natal, RN, Brazil (donis.alfredo@yahoo.com.br) \\ ${ }_{2}^{2}$ Instituto Nacional de Pesquisa da Amazônia, Departamento de Ecologia, Coordenação de Pesquisas em Ecologia, Av. \\ Efigênio Sales, 2239, BOX 2239, Coroado, 69011-970, Manaus, AM, Brazil (saci007@ gmail.com) \\ ${ }^{3}$ Universidade Federal do Paraná, R. Pioneiro, 2153, Jardim Dallas, 85950-000, Palotina, PR, Brazil \\ (cortezvg@yahoo.com.br) \\ ${ }^{4}$ Universidade Federal do Rio Grande do Norte, Departamento de Botânica, Ecologia, Zoologia, Campus Universitário, \\ 59072-970, Natal, RN, Brazil (baseia@ cb.ufrn.br)
}

Alfredo DS, Leite AG, Braga-Neto R, Cortez VG, Baseia IG 2012 - Scleroderma minutisporum, a new earthball from the Amazon rainforest. Mycosphere 3(3), 294-299, Doi 10.5943 /mycosphere/3/3/4

A new species of earthball, Scleroderma minutisporum was found in the Brazilian Amazon. The specimen, collected in Adolpho Ducke Forest Reserve, Amazonas State, Brazil is named because of the small size of its basidiospores. A description, photographs, and taxonomical comments are provided, and the holotype is compared with related taxa.

Key words - Basidiomycota - Boletales - Gasteromycetes - Neotropics - Taxonomy

\section{Article Information}

Received 23 March 2012

Accepted 11 April 2012

Published online 11 May 2012

*Corresponding author: Iuri Goulart Baseia - e-mail - baseia @ cb.ufrn.br

\section{Introduction}

Scleroderma Pers. is a genus of earthballs with a worlwide distribution, from tropical to temperate areas. The taxonomy of the genus has been based mostly on basidiospore features, as well details of the structure and dehiscence of the peridium (Guzmán 1970). Basidiospore features such as size and pattern of the ornamentation were used by Guzmán (1970) and Sims et al. (1995) to produce keys in a worldwide basis. Both authors emphasized the importance of this morphological feature in the taxonomy of this group of fungi. Recent molecular studies supported the accommodation of Scleroderma in the Boletales (Binder \& Bresinsky 2002) and confirmed that ornamentation pattern is, in fact, an informative character for the genus (Phosri et al. 2009, Nouhra et al. 2012).

In a checklist of gasteroid fungi from
Brazil, Trierveiler-Pereira \& Baseia (2009) reported fourteen species of Scleroderma, mostly recorded from southern and northeasttern regions of the country. From the Brazilian Amazon, only S. stellatum Berk.; has been registered, although five species were cited from Venezuelan Amazon by Dennis (1970). Several species of Scleroderma that were reported from the Neotropical region are known to be exotic and introduced, especially with Pinus and Eucalyptus shoots (Giachini et al. 2000). However, native species of earthballs have been recorded from different autochthonous vegetation types in Brazil (Baseia \& Milanez 2000, Gurgel et al. 2008, Cortez et al. 2011). In the present study, we provide the description of a new species in the genus Scleroderma from native Amazon rainforest, as part of a survey of gasteromycetes in progress (Leite et al. 2011, Trierveiler 

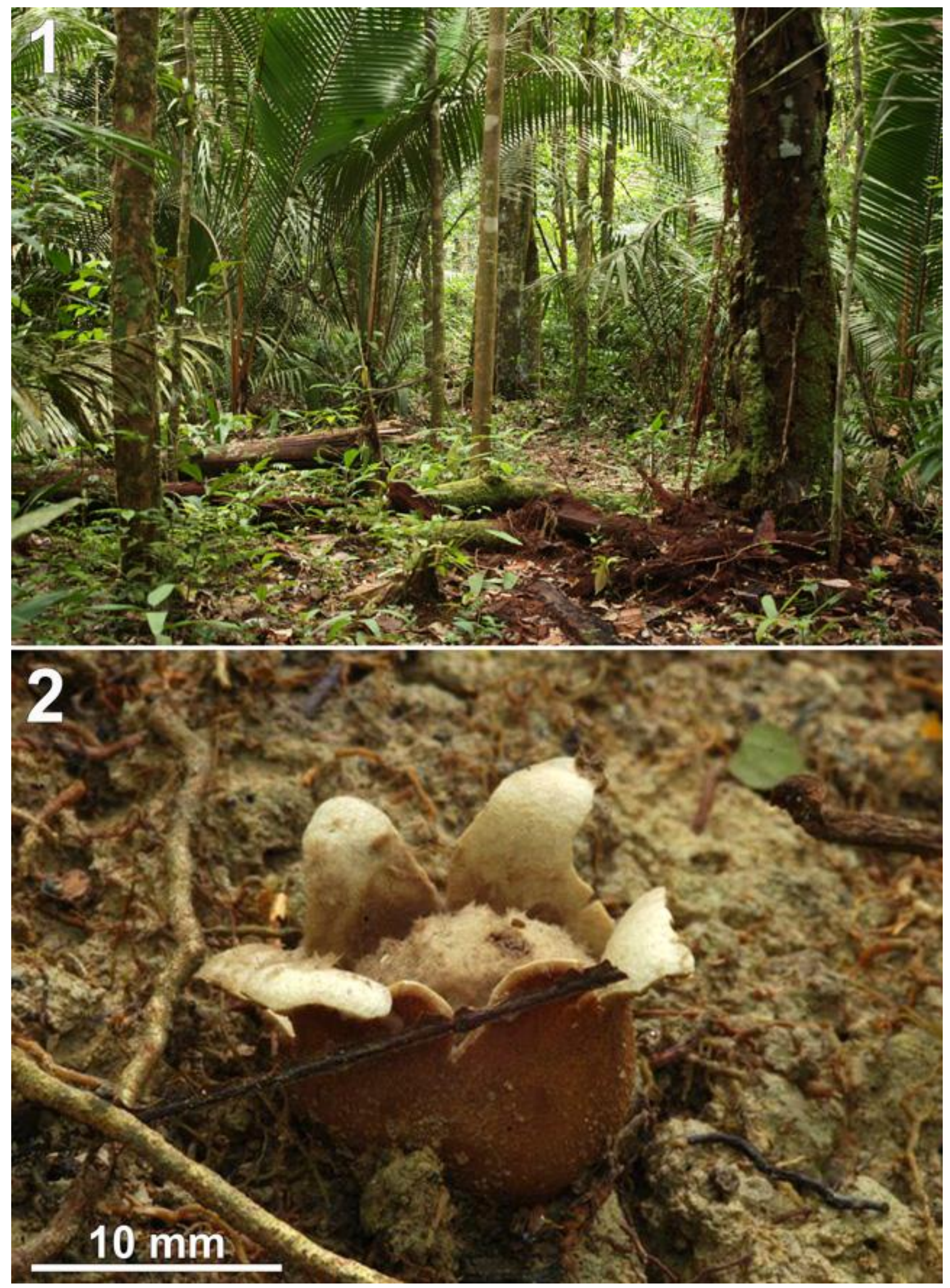

Figs 1-2 - Scleroderma minutisporum. 1 Amazon forest, Ducke Forest Reserve (type locality). 2 Mature basidioma (holotype). 
-Pereira et al. 2012, Alfredo et al. 2012).

\section{Methods}

Basidiomata were collected during the rainy season of 2008 (January), in the Adolpho Ducke Reserve Forest, Manaus, AM, Brazil (Fig. 1). Fresh specimens were photographed and examined in the field. Macroscopic characters were described following observation of fresh and dried material. Microscopic observations were made from sections of peridium and gleba mounted in $5 \% \mathrm{KOH}$, in lactophenol (Guzmán et al. 2004) on glass slides and observed under an Olympus BX41 light microscope (LM). Fifty randomly selected basidiospores were measured (including the ornamentation) under the LM at 1000x magnification. The basidiospores were examined under a Philips XL20 scanning electron microscopy (SEM), following Baseia $\&$ Calonge (2008). Colors were based on Kornerup \& Wanscher (1978) and voucher specimens are deposited in the INPA Herbarium.

\section{Results}

Scleroderma minutisporum Baseia, Alfredo \& Cortez, sp. nov.

MycoBank

564898

(http://www.mycobank.org).

Etymology - Named in reference to the small size of the basidiospores.

Diagnosis - Basidiomata 18-20 mm diam., fresh peridium $<1 \mathrm{~mm}$ thick, with stellate dehiscence and basidiospores 4-7 $\mu \mathrm{m}$ diam. (including the reticulate ornamentation).

Basidiomata epigeous, sessile, subglobose, $18-20 \mathrm{~mm}$ high, $16-17 \mathrm{~mm}$ broad; peridium subcoriaceous, three layered, thin, when fresh about $0.8-1 \mathrm{~mm}$ thick, when dry about $0.4-0.6 \mathrm{~mm}$ thick, upper portion opening by stellate dehiscence that produces 5-6 irregular lobes, basal portion with scarce rhizomorphs; exoperidium reddish brown (KW 8E7), velutinous to asperulate, sub-coriaceous, composed of hyphae 3-6 $\mu \mathrm{m}$ diam., clamp connection present, yellowish brown in 5\% $\mathrm{KOH}$; mesoperidium inconspicuous, hyphae hyaline to pale yellow in $5 \% \mathrm{KOH}$, mucilaginous substance present; endoperidium greyish orange (KW 5B3), cellular, formed by
15-40 × 50-90 $\mu \mathrm{m}$ diam. hyphae, hyaline, thick-walled, pale yellow in $5 \% \mathrm{KOH}$; gleba cottonose, greyish brown (KW 6D3); basidiospores 4-7 $\mu \mathrm{m}$ diam. under LM and 3.8-7.3 $\mu \mathrm{m}$ diam. under SEM, irregularly reticulate, yellowish brown in $5 \% \mathrm{KOH}$, usually mixed with remains of the cellular endoperidium.

Habitat - Solitary on soil, rhizomorphs aggregated with roots of native trees (Fig. 1).

Known distribution - Amazon rainforest, Brazil.

Material examined - Brazil, Manaus, Adolpho Ducke Forest Reserve, on soil, 28 January 2008, leg. R. Braga-Neto, RBN 664 (INPA 220507, Holotype).

\section{Discussion}

Scleroderma minutisporum exhibits distinct morphological features such as small basidiomata ( $<20 \mathrm{~mm}$ diam.), thin peridium ( $<1 \mathrm{~mm}$ thick - Fig. 2), and the smallest reticulate basidiospores observed to date in the genus (4-7 $\mu \mathrm{m}$ diam. - Fig. 3). Studies conducted by Guzmán (1970) and Guzmán et al. (2004) on the holotypes of S. sinnamariense Mont., S. bermudense Coker and S. stellatum demonstrate that they also have small basidiospores less than $5 \mu \mathrm{m}$ in diameter. The ornamentation pattern observed in $S$. minutisporum also differs from those found in other species. (Table 1).

Scleroderma bermudense, S. sinnamariense and $S$. stellatum present echinulate basidiospores and are included in Scleroderma Sect. Sclerangium (Guzmán 1970). According to Guzmán (1970) and Sims et al. (1995), representatives of the genus that exhibit a reticulate ornamentation pattern are classified in Scleroderma Sect. Scleroderma, with $S$. dictyosporum Pat. as the member with smallest basidiospore size (Table 1). The set of morphological data show that $S$. minutisporum is a species distinct from others in the genus and, based on the reticulate ornamentation pattern, this new taxon belongs in Sect. Scleroderma, making it the species with the smallest basidiospores in this gasteroid genus.

Recent biochemical studies have suggested the healing potential of certain polysaccharides synthesized by Scleroderma nitidum Berk. (Nascimento et al. 2012). The 
Table 1 Basidiospore characters of Scleroderma minutisporum compared to similar species.

\begin{tabular}{llll}
\hline Species & Ornamentation & $\begin{array}{l}\text { Spore size } \\
(\mu \mathrm{m})\end{array}$ & References \\
\hline S. bermudense & Strongly echinulate & $5-10$ & Guzmán et al. (2004) \\
S. dictyosporum & Strongly and strikingly reticulate & $9-14$ & Guzmán (1970) \\
S. minutisporum & Irregularly reticulate & $4-7$ & Present work \\
S. sinnamariense & Echinulate to finely reticulate & $7-9$ & Guzmán \& Ovrebo (2000) \\
S. stellatum & Strongly echinulate & $5-9$ & Guzmán et al. (2004) \\
\hline
\end{tabular}

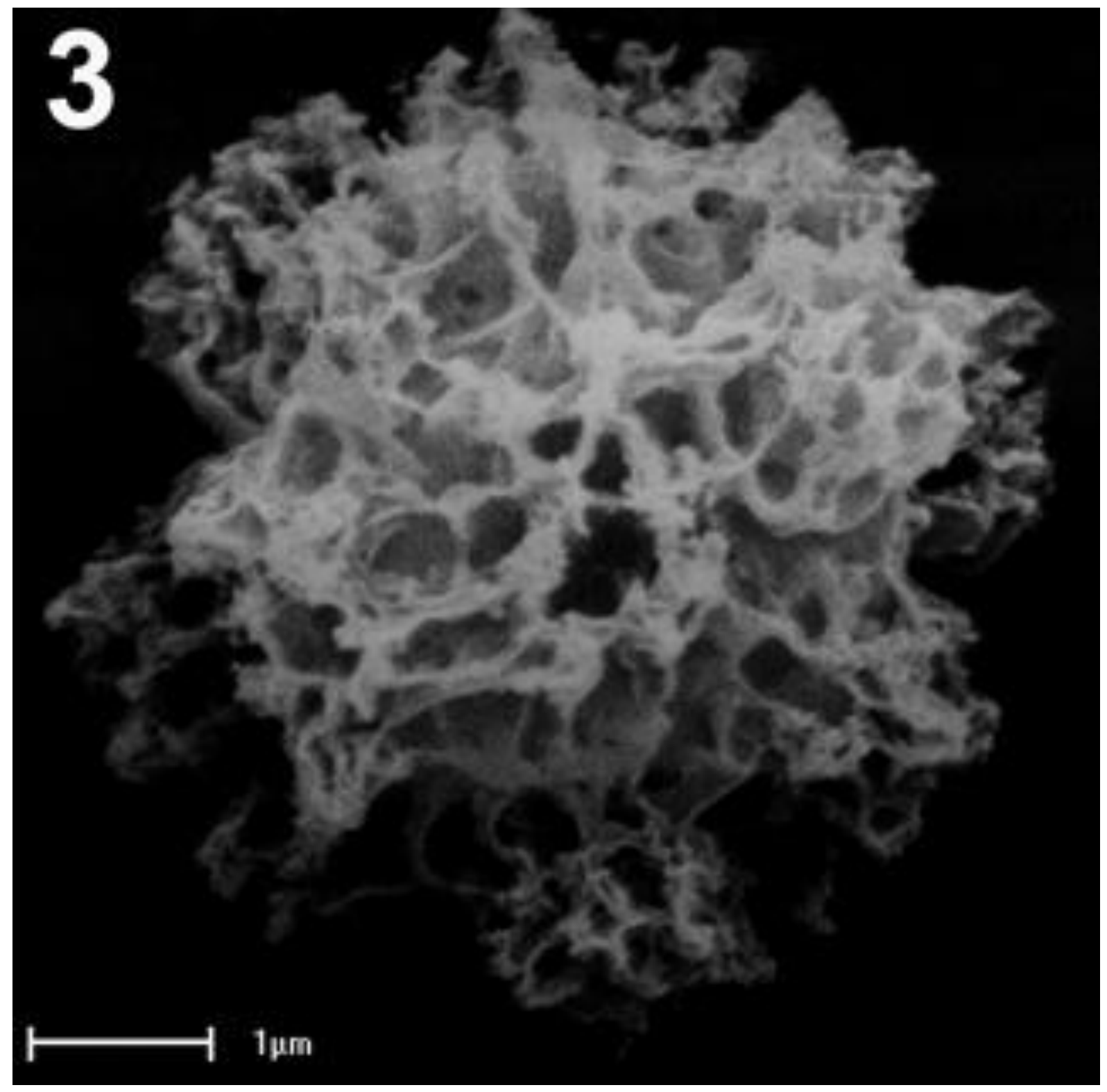

Fig. 3 - Scleroderma minutisporum. Basidiospore under SEM. 
potential of bioproducts derived from these species is enormous and thus, the continuing studies on the species diversity are essential to both basic and applied research.

\section{Acknowledgements}

The first author would like to thank CNPq (Conselho Nacional de Desenvolvimento Científico e Tecnológico, Brazil) for providing the Master's scholarship and financial support. The authors also acknow-edge Dr. Carlos Franciscon, Curator of INPA Herbarium, for loan of exsiccates and the CTPETROINFRA and FINEP/LIEM for their collaboration with scanning electron microscopy.

\section{References}

Alfredo DS, Leite AG, Braga-Neto R, Baseia IG. 2012 - Two new Morgane-lla species from the Brazilian Amazon rainforest. Mycosphere 3, 66-71.

Baseia IG, Calonge FD. 2008 - Calvatia sculpta, a striking puffball occurring on Brazilian sand dunes. Mycotaxon 106, 269-272.

Baseia IG, Milanez AI. 2000 - Primeiro registro de Scleroderma polyrhizum Pers. (Gasteromycetes) para o Brasil. Acta Botanica Brasilica 14, 181-184.

Binder M, Bresinsky A. 2002 - Derivation of a polymorphic lineage of gasteromycetes from boletoid ancestors. Mycologia 94, 85-98.

Cortez VG, Baseia IG, Silveira RMB. 2011. Gasteroid mycobiota of Rio Grande do Sul, Brazil: Boletales. Journal of Yeast and Fungal Research 2, 44-52.

Dennis RWG. 1970 - Fungus flora of Venezuela and adjacent countries. Kew Bulletin Additional Series 3, 1-531.

Giachini AJ, Oliveira VL, Castellano MA, Trappe JM. 2000 - Ectomycorrhizal fungi in Eucalyptus and Pinus plantations in Southern Brazil. Mycologia 92, 11661177.

Gurgel FE, Silva BDB, Baseia IG. 2008 - New records of Scleroderma from Northeastern Brazil. Mycotaxon 105, 399-405.

Guzmán G. 1970 - Monografía del género Scleroderma Pers. emend. Fr. (Fungi,
Basidiomycetes). Darwiniana 16, 233407.

Guzmán G, Ovrebo CL. 2000 - New observations on sclerodermataceous fungi. Mycologia 92, 171-179.

Guzmán G, Ramírez-Guillén F, Miller OK Jr., Lodge DJ, Timothy JB. 2004 Scleroderma stellatum versus Scleroderma bermudense: the status of Scleroderma echinatum and the first record of Veligaster nitidum from the Virgin Islands. Mycologia 96, 1370-1379.

Kornerup A, Wanscher JH. 1978 - Methuen handbook of colour. $3^{\text {rd }}$ ed. Eyre Methuen. London.

Leite AG, Assis HK, Silva BDB, Sotão HMP, Baseia IG. 2011 - Geastrum species from the Amazon Forest, Brazil. Mycotaxon 118, 383-392.

Nascimento MS, Magalhães JEM, Pinheiro TS, Silva TA, Coutinho LG, Baseia IG, Lima LFA, Leite EL. 2012 - Polysaccharides from the fungus Scleroderma nitidum with anti-inflammatory potential modulate cytokine levels and the expression of nuclear factor $\mathrm{kB}$. Brazilian Journal of Pharmacognosy 22, 60-68.

Nouhra ER, Caffot MLH, Pastor N, Crespo EM. 2012 - The species of Sclero-derma from Argentina, including a new species from the Nothofagus forest. Mycologia 104, 488-495.

Phosri C, Martín MP, Watling R, Jeppson M, Sihanonth P. 2009 - Molecular phylogeny and re-assessment of some Scleroderma spp. (Gasteromycetes). Anales del Jardin Botánico de Madrid 66S1, 83-91.

Sims KP, Watling R, Jeffries P. 1995 - A revised key to the genus Scleroderma. Mycotaxon 51, 403-420.

Trierveiler-Pereira L, Baseia IG. 2009 Checklist of the Brazilian gasteroid fungi (Basidiomycota). Mycotaxon 108, 441444.

Trierveiler-Pereira L, Gomes-Silva AC, Baseia IG. 2012. - Observations on gasteroid Agaricomycetes from the Brazilian Amazon rainforest. Mycotaxon 118, 273-282. 